\title{
Morphologic Analysis of Cytomegalovirus Infected Cells in Bronchial Washing Cytology: Comparison of Liquid-Based Preparation and Conventional Smear
}

Jae Yeon Seok* · Jungsuk An* Seung Yeon Ha · Dong Hae Chung Sangho Lee $\cdot$ Hyunchul Kim

Department of Pathology, Gachon University Gil Medical Center, Incheon, Korea

Received: November 3, 2015

Revised: December 15, 2015

Accepted: December 24, 2015

\section{Corresponding Author}

Seung Yeon $\mathrm{Ha}$, MD, PhD

Department of Pathology, Gachon University Gil Medical Center, 21 Namdong-daero 774beon-gil, Namdong-gu, Incheon 21565, Korea

Tel: +82-32-460-3073

Fax: +82-32-460-2394

E-mail: syha@gilhospital.com

*Jae Yeon Seok and Jungsuk An contributed equally to this work.
Background: The cytopathic effects of cytomegalovirus (CMV) infection have been well described since the virus was first reported; however, the morphology of CMV infection has not been clearly studied. We examined the difference in detailed cytologic findings in bronchial washing cytology between liquid-based and conventionally prepared smears. Methods: Bronchial washing cytology was processed using either the conventional preparation (CP) or liquid-based preparation (LBP). Sixty-nine cells with typical cytopathic effects of CMV infection were detected on CP slides and 18 cells on LBP slides. Using the image analyzer, area, circumference, major axis, and minor axis of the cytoplasm, nucleus, and intranuclear inclusion were measured in singly scattered CMV-infected cells, and histiocytes were used as a control. Results: The mean cytoplasmic area of CMVinfected cells was 1.47 times larger than that of histiocytes in CP and 2.92 times larger in LBP ( $p$ $<.05)$. The mean nuclear area of CMV-infected cells was 2.61 times larger than that of histiocytes in $\mathrm{CP}$ and 4.25 times larger in LBP $(\mathrm{p}<.05)$. The nucleus to cytoplasm ratio and intranuclear inclusion to cytoplasm ratio of the mean area, circumference, major axis, and minor axis in CP were larger than those in LBP $(p<.05)$. Conclusions: The sizes of cytoplasm, nucleus, and intranuclear inclusion were larger in LBP than in CP, indicating that CMV-infected cells are easily detectable in LBP. However, the nucleus-to-cytoplasm ratio was larger in $\mathrm{CP}$, suggesting that differentiation from malignancy or regenerative atypia requires caution in $\mathrm{CP}$.

Key Words: Cytomegalovirus; Bronchial washing; Cytology; Lung
The morphologic alteration of cytomegalovirus (CMV) infected cells is well described in that they have enlarged cytoplasm and nuclei, sharply demarcated nuclear membranes, and chromatin condensation with a surrounding halo. A distinguishing feature of CMV-infected cells was first described by Ribbert ${ }^{1}$ in kidney and parotid glands of a syphilitic stillborn in $1904{ }^{2}$ Jesionek and Kiolemenoglou ${ }^{3}$ reported similar unusually large cells as protozoan-like cells and clearly described the cellular morphology: the cells were 20-30 $\mu \mathrm{m}$ in diameter, with large eccentrically placed nuclei. Each contained a 'central nuclear body' surrounded by two zones, a darker inner zone and a clear outer zone. $^{3}$ In 1921, Goodpasture and Talbot ${ }^{4}$ suggested that these cells were similar to Varicella-infected cells of the skin and that they were products of viral infection, and thus they were named cytomegalia infantum. Cole and Kuttner ${ }^{5}$ demonstrated inclusion body formation by viral injection into guinea pig cells. Various terminologies have been used for CMV, including "salivary gland virus disease," "inclusion body disease," "generalized sali- vary gland virus infection," "inclusion disease," and "cytomegalic inclusion disease." In 1957, Weller isolated viral particles from cells of cytomegalic inclusion disease and suggested CMV as the etiologic virus. ${ }^{6}$ However, the exact size of enlarged CMV-infected cells has not been studied in detail.

CMV is a common infectious agent in immunocompromised hosts, and early detection is clinically important. The characteristic features have been used for pathognomonic diagnostic findings of CMV infections in various cytology specimens, including urine, sputum, bronchial brushing, and bronchoalveolar lavage. $^{7-11}$ In practice, the first diagnosis that used cytologic preparation was made by Fetterman in $1952 .^{7}$ Urine was obtained from a 2-day-old premature infant; after alcohol fixation and hematoxylin and eosin staining, several inclusion containing cells with enormous cellular hypertrophy and large intranuclear inclusions were observed in urine exfoliative cytology. The infant died of generalized inclusion disease, and typical inclusions were found in tissue sections of the brain, pituitary gland, thyroid 
gland, lungs, liver, pancreas, and kidneys. In 1964, Warner et al. ${ }^{8}$ described the cellular morphology of CMV-infected cells in sputum cytology. CMV-infected cells in sputum contained a spherical nucleus, sharply demarcated nuclear membrane, centrally located chromatin mass surrounded by halo, and an occasional binucleated form that resembled a syncytium. In a tissue section of lung in this patient, typical cytomegaly with nuclear inclusion was observed throughout the alveolar spaces and septa, measuring 15-25 $\mu \mathrm{m}$ in cell size. Round or oval nuclear inclusion with halo, sharply delineated nuclear membrane, parabasal bodies, and occasional clusters of cytoplasmic inclusions were noted. Although detection of CMV-infected cells in cytology specimens is a less sensitive method than virus isolation, it is quite time saving in terms of effectiveness. Culture for viral isolation requires several weeks, and CMV titer in serology also requires weeks before diagnosis. Detection of CMV-infected cells using a cytologic specimen is an easy and widely used approach in immunocompromised patients and in those with conditions suspicious for congenital infection.

The application of cytologic specimens associated with respiratory tract infection including sputum, bronchial brushing, bronchoalveolar lavage, bronchial washing, and fine-needle aspiration was well-defined in a clinical setting of acquired immunodeficiency syndrome, idiopathic pulmonary fibrosis, lung transplantation, and kidney transplantation. ${ }^{8-15}$ Cytology specimens of other organs described as diagnostic tools for CMV infection including uterine cervical Pap smear, ${ }^{16-21}$ salivary gland aspiration, ${ }^{22,23}$ pleural fluid, ${ }^{24-26}$ cerebrospinal fluid, ${ }^{27}$ esophagus, ${ }^{28}$ and thyroid aspiration ${ }^{29}$ have been reported. In cytologic specimens, the individual cellular morphology is well-preserved, and the diagnostic usability is particularly useful for CMV infection in which cellular alteration is pathognomonic.

In liquid-based preparation (LBP), the cytologic detail of CMV infection has not been described except in two gynecologic samples, which highlighted the difference between CMV and human papillomavirus infection. ${ }^{19,30}$ Several studies that compared the difference between LBP and conventional preparation (CP) in cytologic specimens focused mainly on neoplastic diseases. ${ }^{31-40}$ We studied the difference in detailed cytologic findings between bronchial washing in LBP and CP for cellular morphologic parameters.

\section{MATERIALS AND METHODS}

\section{Patient selection}

Five cases diagnosed with CMV infection based on bronchial washing cytology specimens at Gachon University Gil Medical Center between 2003 and 2014 were selected and reviewed. This study was approved by the Institutional Review Board (IRB) of Gachon University Gill Medical Center (IRB No. GBIRB 2015-284). Clinical information on the five patients is summarized in Table 1. Each bronchial washing cytology specimen was treated in CP and LBP.

\section{Cytologic preparations}

The obtained samples were treated with both CP and LBP, simultaneously. The bronchus was washed with normal saline, and the washing samples were centrifuged for five minutes. The cytospin technique was used as in the $\mathrm{CP}$ method. The sample was centrifuged (2,000 rpm, 5 minutes), and two cytospins (1,500 rpm, 4 minutes) were prepared for each bronchial washing sample. Slides were fixed in 95\% alcohol for 60 minutes and stained with a Papanicolaou stain. For LBP, mucolysis was performed using dithrothreitol. After rinsing with Cytolyt (Cytyc Co., Boxborough, MA, USA), the sample was centrifuged for five minutes at 1,500 rpm. The supernatant was discarded,

Table 1. Clinical history of patients with cytomegaloviral infection detected in bronchial washing cytology and the number of cytomegalovirus infected cells and histiocytes by the cytologic preparation method

\begin{tabular}{|c|c|c|c|c|c|c|c|c|}
\hline No. & Sex & $\begin{array}{l}\text { Age } \\
(y r)\end{array}$ & History & Other finding & $\begin{array}{l}\text { CMVinf- } \\
\text { CP }\end{array}$ & $\begin{array}{l}\text { CMVinf- } \\
\text { LBP }\end{array}$ & $\begin{array}{l}\text { Histiocyte- } \\
\text { CP }\end{array}$ & $\begin{array}{l}\text { Histiocyte- } \\
\text { LBP }\end{array}$ \\
\hline 1 & $\mathrm{~F}$ & 39 & Renal transplantation ${ }^{a}$ & Serum cytomegalovirus $>1,000$ & 9 & 0 & 7 & 0 \\
\hline 2 & M & 45 & Renal transplantation ${ }^{a}$ & Acute rejection & 1 & 0 & 1 & 0 \\
\hline 3 & M & 18 & Bone marrow transplantation ${ }^{\mathrm{b}}$ & $\begin{array}{l}\text { Cytomegalovial retinitis, influenza A } \\
\text { virus + }\end{array}$ & 15 & 5 & 11 & 1 \\
\hline 4 & $\mathrm{~F}$ & 66 & Myasthenia gravis & $\begin{array}{l}\text { Aspergillus antigen }+ \text {, gram-positive } \\
\text { bacteremia }\end{array}$ & 27 & 12 & 55 & 21 \\
\hline 5 & M & 71 & $\begin{array}{l}\text { Acquired immunodeficiency } \\
\text { syndrome }\end{array}$ & Cytomegalovirus PCR +, tuberculosis & 17 & 1 & 36 & 0 \\
\hline
\end{tabular}

CMVinf-CP, cytomegalovirus infected-cells in smear processed by conventional preparation; CMVinf-LBP, cytomegalovirus infected-cells in cytology processed by liquid-based preparation; Histiocyte-CP, histiocytes in smear processed by conventional preparation; Histiocyte-LBP, histiocytes in cytology processed by liquid-based preparation; PCR, polymerase chain reaction.

${ }^{a}$ Chronic renal failure; ${ }^{b}$ Aplastic anemia. 
and the sample was transferred to a vial containing cytopreservative solution (PreservCyt, Cytyc Co.). PreservCyt solution mildly fixed the cells for 15 minutes. The sample was run on a ThinPrep Processor (Cytyc Co.) using sequence 3 (for mucoid specimen). A single slide was prepared for each sample and was stained using the Papanicolaou method.

\section{Imaging and analysis}

Using a DP70 digital camera (Olympus, Tokyo, Japan) and BX51 microscope (Olympus), pictures were taken at high power magnification $(\times 1,000)$ for each singly scattered CMV-infected cell and histiocyte. Cells with artifacts such as drying, squeezing, and overlapping were excluded. Sixty-nine cells with typical cytopathic effects of CMV infection on CP slides and 18 cells on LBP slides were selected (patient 1, 9 cells on CP; patient 2, 1 cell on CP; patient 3, 15 cells on CP and 5 cells on LBP; patient 4, 27 cells on CP and 12 cells on LBP; patient 5, 17 cells on CP and 1 cell on LBP) (Table 1). The area, circumference, major axis, and minor axis of cytoplasm, nucleus, and intranuclear inclusion were measured using the image analyzer software package i-Solution ver. 10.1 (IMT i-Solution, Vancouver, BC, Canada). The major axis was the longest diameter, and the minor axis was the dimension perpendicular to the major axis (Fig. 1A, B).

\section{Statistical analysis}

SPSS ver. 18.0 (SPSS Inc., Chicago, IL, USA) was used for statistical analysis. Student's t test was used to compare the area,

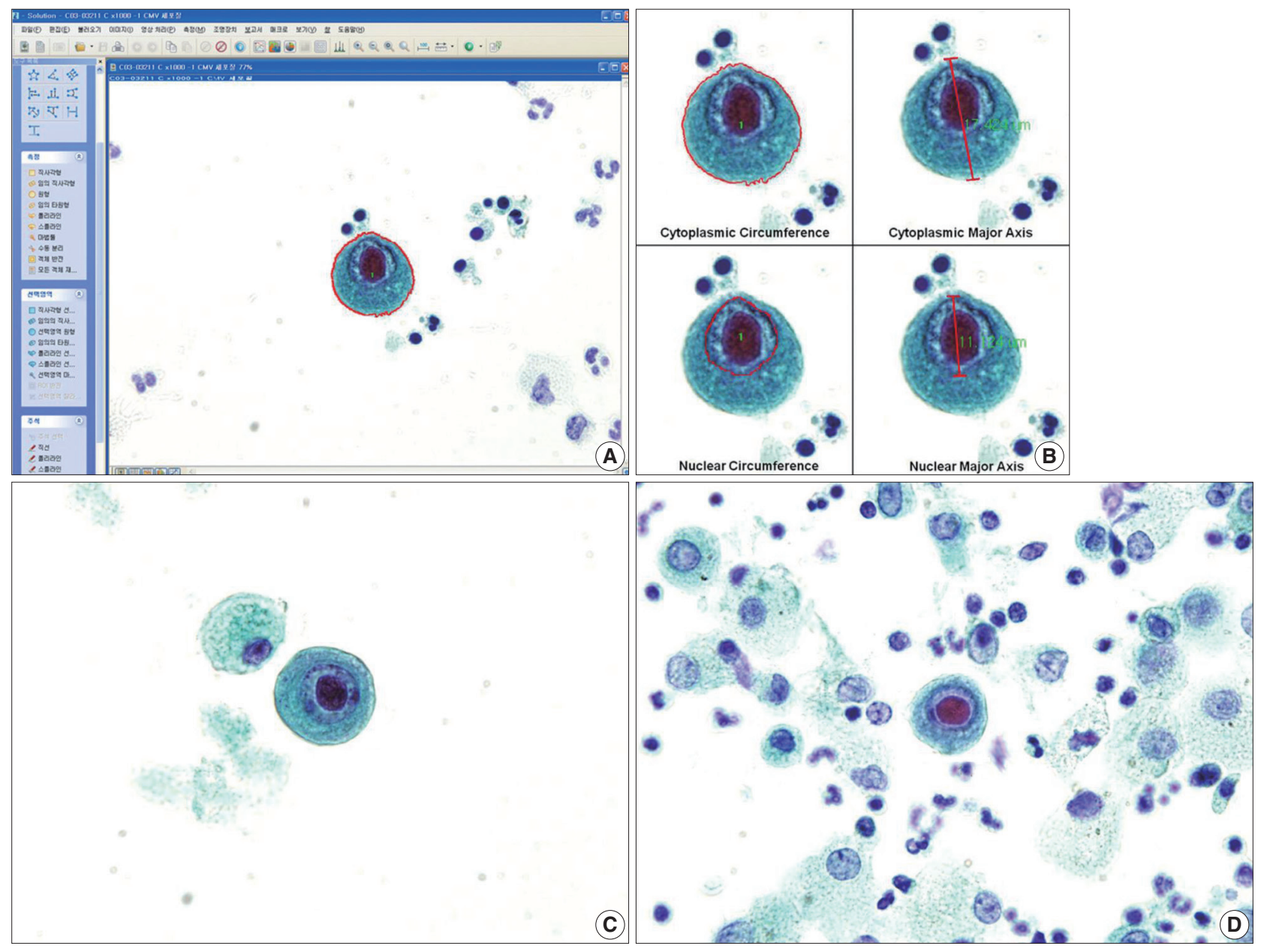

Fig. 1. (A, B) Well-prepared microscopic photographs from the image analyzer program. Specific shape and color are detected by the program. The researcher selects an area of interest, and the area, circumference, major axis, and minor axis are automatically calculated by the image analyzer. The major axis is the longest diameter, and the minor axis is the dimension perpendicular to the major axis. (C) A singly scattered cytomegalovirus infected cell and a histiocyte in a cytology specimen processed by liquid-based preparation are noted with a clean background. The cytoplasm and nucleus are enlarged and show dense cytoplasm with a well-demarcated cytoplasmic border. (D) In a conventionally-prepared cytology smear, a cytomegalovirus infected cell shows a prominent intranuclear inclusion. 
circumference, major axis, and minor axis results to assess the differences in CMV-infected cells and histiocytes in each preparation method and the differences in CMV-infected cell morphology in different preparations. A p-value less than .05 was considered statistically significant.

\section{RESULTS}

\section{CMV-infected cell morphology in bronchial washing cytology}

Sixty-nine cells with typical cytopathic effects of CMV infection were detected on CP slides, and 18 cells were noted on LBP slides (Fig. 1C, D). Each CMV-infected cell was singly scattered with an enlarged cytoplasm and nucleus, compared to histiocytes around the cell. The nuclear membrane was distinct, and a well-demarcated large intranuclear inclusion was observed with a peri-inclusion halo. Cytoplasmic inclusion was variably noted.

\section{CMV-infected cells and histiocytes in CP}

Details on the morphologic parameter measurements are shown in Tables 2 and 3. The mean cytoplasmic area of CMVinfected cells was $189.94 \pm 49.27 \mu^{2}(t=8.136, p<.001)$, and the mean nuclear area of $\mathrm{CMV}$-infected cells was $73.87 \pm 19.54$ $\mu^{2}{ }^{2}(t=18.021, p<.001)$. The nucleus to cytoplasm ratio of the mean area in $\mathrm{CMV}$-infected cells was $0.40 \pm 0.09(\mathrm{t}=13.817$, $\mathrm{p}<.001)$.

\section{CMV-infected cells and histiocytes in LBP}

The mean cytoplasmic area of CMV-infected cells was $299.74 \pm$ $94.90 \mathrm{\mu m}^{2}(\mathrm{t}=8.414, \mathrm{p}<.001)$, and the mean nuclear area of

Table 2. Comparison of cellular morphology

\begin{tabular}{|c|c|c|c|c|c|c|c|c|}
\hline \multirow{2}{*}{ Parameter } & \multirow{2}{*}{$\begin{array}{l}\text { CMVinf-CP (A) } \\
(n=69)\end{array}$} & \multirow{2}{*}{$\begin{array}{l}\text { CMVinf-LBP (B) } \\
\quad(n=18)\end{array}$} & \multirow{2}{*}{$\begin{array}{l}\text { Histiocyte-CP (C) } \\
\quad(n=110)\end{array}$} & \multirow{2}{*}{$\begin{array}{l}\text { Histiocyte-LBP (D) } \\
\quad(n=22)\end{array}$} & \multicolumn{4}{|c|}{$p$-value } \\
\hline & & & & & $A$ vs $B$ & A vs $C$ & B vs D & C vs D \\
\hline \multicolumn{9}{|l|}{ Cytoplasm } \\
\hline Area $\left(\mu m^{2}\right)$ & $189.94 \pm 49.27$ & $299.74 \pm 94.90$ & $129.48 \pm 47.82$ & $102.64 \pm 50.39$ & $.000^{*}$ & $.000^{*}$ & $.000^{*}$ & $.019^{*}$ \\
\hline Circumference $(\mu \mathrm{m})$ & $59.26 \pm 10.81$ & $74.59 \pm 17.56$ & $56.76 \pm 15.76$ & $50.55 \pm 24.03$ & $.000^{*}$ & .209 & $.001^{*}$ & .128 \\
\hline Major axis $(\mu \mathrm{m})$ & $15.89 \pm 2.26$ & $19.87 \pm 2.92$ & $13.29 \pm 2.62$ & $11.74 \pm 2.93$ & $.000^{*}$ & $.000^{*}$ & $.000^{*}$ & $.014^{*}$ \\
\hline Minor axis $(\mu \mathrm{m})$ & $15.71 \pm 2.27$ & $19.60 \pm 3.29$ & $13.35 \pm 2.72$ & $11.50 \pm 2.70$ & $.000^{*}$ & $.000^{*}$ & $.000^{*}$ & $.004^{*}$ \\
\hline \multicolumn{9}{|l|}{ Nucleus } \\
\hline Area $\left(\mu m^{2}\right)$ & $73.87 \pm 19.54$ & $100.89 \pm 47.87$ & $28.35 \pm 9.64$ & $23.76 \pm 8.43$ & $.030^{*}$ & $.000^{*}$ & $.000^{*}$ & $.039^{*}$ \\
\hline Circumference $(\mu \mathrm{m})$ & $34.92 \pm 5.50$ & $40.00 \pm 7.99$ & $21.43 \pm 3.82$ & $20.15 \pm 4.48$ & $.002^{*}$ & $.000^{*}$ & $.000^{*}$ & .164 \\
\hline Major axis $(\mu \mathrm{m})$ & $9.94 \pm 1.53$ & $11.72 \pm 2.88$ & $6.18 \pm 1.21$ & $5.81 \pm 1.44$ & $.020^{*}$ & $.000^{*}$ & $.000^{*}$ & .201 \\
\hline Minor axis $(\mu m)$ & $9.91 \pm 1.42$ & $11.58 \pm 2.08$ & $6.06 \pm 1.15$ & $5.50 \pm 1.10$ & $.000^{*}$ & $.000^{*}$ & $.000^{\star}$ & $.038^{*}$ \\
\hline \multicolumn{9}{|l|}{$\mathrm{N} / \mathrm{C}$ ratio } \\
\hline Area $\left(\mu m^{2}\right)$ & $0.40 \pm 0.09$ & $0.33 \pm 0.07$ & $0.23 \pm 0.07$ & $0.26 \pm 0.09$ & $.005^{*}$ & $.000^{*}$ & $.008^{*}$ & .174 \\
\hline Circumference( $\mu \mathrm{m})$ & $0.60 \pm 0.09$ & $0.54 \pm 0.07$ & $0.40 \pm 0.10$ & $0.44 \pm 0.13$ & $.021^{*}$ & $.000^{*}$ & $.002^{\star}$ & .092 \\
\hline Major axis $(\mu \mathrm{m})$ & $0.63 \pm 0.08$ & $0.59 \pm 0.07$ & $0.48 \pm 0.10$ & $0.51 \pm 0.13$ & $.049^{*}$ & $.000^{*}$ & $.020^{*}$ & .187 \\
\hline Minor axis $(\mu \mathrm{m})$ & $0.64 \pm 0.08$ & $0.59 \pm 0.07$ & $0.46 \pm 0.09$ & $0.49 \pm 0.10$ & .053 & $.000^{*}$ & $.001^{*}$ & .217 \\
\hline \multicolumn{9}{|l|}{ INI } \\
\hline Area $\left(\mu m^{2}\right)$ & $29.48 \pm 8.46$ & $36.94 \pm 14.23$ & - & - & $.006^{*}$ & & & \\
\hline Circumference $(\mu \mathrm{m})$ & $22.51 \pm 3.23$ & $26.20 \pm 4.81$ & - & - & $.006^{\star}$ & & & \\
\hline Major axis $(\mu \mathrm{m})$ & $6.27 \pm 1.17$ & $7.05 \pm 1.41$ & - & - & $.017^{*}$ & & & \\
\hline Minor axis $(\mu \mathrm{m})$ & $6.50 \pm 1.06$ & $7.28 \pm 1.48$ & - & - & $.013^{*}$ & & & \\
\hline \multicolumn{9}{|l|}{ INI/N ratio } \\
\hline Area $\left(\mu m^{2}\right)$ & $0.41 \pm 0.09$ & $0.38 \pm 0.09$ & - & - & .282 & & & \\
\hline Circumference $(\mu \mathrm{m})$ & $0.65 \pm 0.08$ & $0.66 \pm 0.10$ & - & - & .597 & & & \\
\hline Major axis $(\mu \mathrm{m})$ & $0.63 \pm 0.09$ & $0.61 \pm 0.09$ & - & - & .345 & & & \\
\hline Minor axis $(\mu \mathrm{m})$ & $0.66 \pm 0.09$ & $0.63 \pm 0.08$ & - & - & .199 & & & \\
\hline \multicolumn{9}{|l|}{ INI/C ratio } \\
\hline Area $\left(\mu m^{2}\right)$ & $0.16 \pm 0.04$ & $0.12 \pm 0.02$ & - & - & $.000^{\star}$ & & & \\
\hline Circumference $(\mu \mathrm{m})$ & $0.39 \pm 0.07$ & $0.36 \pm 0.05$ & - & - & .075 & & & \\
\hline Major axis $(\mu \mathrm{m})$ & $0.40 \pm 0.06$ & $0.35 \pm 0.04$ & - & - & $.002^{*}$ & & & \\
\hline Minor axis $(\mu m)$ & $0.42 \pm 0.07$ & $0.37 \pm 0.05$ & - & - & $.010^{\star}$ & & & \\
\hline
\end{tabular}

CMVinf-CP, cytomegalovirus infected cells in smear processed by conventional preparation; CMVinf-LBP, cytomegalovirus infected cells in cytology processed by liquid-based preparation; Histiocyte-CP, histiocytes in smear processed by conventional preparation; Histiocyte-LBP, histiocytes in cytology processed by liquid-based preparation; $\mathrm{N}$, nucleus; C, cytoplasm; INI, intranuclear inclusion. ${ }^{*} p<.05$. 
Table 3. Comparison of cytomegalovirus infected cells and histiocytes

\begin{tabular}{|c|c|c|c|c|}
\hline Parameter & CMVinf-CP $(n=69)$ & CMVinf-LBP $(n=18)$ & CMVinf-CP/Histiocyte-CP & CMVinf-LBP/Histiocyte-LBP \\
\hline \multicolumn{5}{|l|}{ Cytoplasm } \\
\hline Area $\left(\mu \mathrm{m}^{2}\right)$ & $189.94 \pm 49.27$ & $299.74 \pm 94.90$ & $1.47^{*}$ & $2.92^{*}$ \\
\hline Circumference $(\mu \mathrm{m})$ & $59.26 \pm 10.81$ & $74.59 \pm 17.56$ & 1.04 & $1.48^{*}$ \\
\hline Major axis $(\mu \mathrm{m})$ & $15.89 \pm 2.26$ & $19.87 \pm 2.92$ & $1.20^{*}$ & $1.69^{*}$ \\
\hline Minor axis $(\mu \mathrm{m})$ & $15.71 \pm 2.27$ & $19.60 \pm 3.29$ & $1.18^{*}$ & $1.70^{*}$ \\
\hline \multicolumn{5}{|l|}{ Nucleus } \\
\hline Area $\left(\mu m^{2}\right)$ & $73.87 \pm 19.54$ & $100.89 \pm 47.87$ & $2.61^{*}$ & $4.25^{\star}$ \\
\hline Circumference $(\mu \mathrm{m})$ & $34.92 \pm 5.50$ & $40.00 \pm 7.99$ & $1.63^{*}$ & $1.99^{*}$ \\
\hline Major axis $(\mu \mathrm{m})$ & $9.94 \pm 1.53$ & $11.72 \pm 2.88$ & $1.61^{*}$ & $2.02^{*}$ \\
\hline Minor axis $(\mu \mathrm{m})$ & $9.91 \pm 1.42$ & $11.58 \pm 2.08$ & $1.64^{*}$ & $2.11^{*}$ \\
\hline \multicolumn{5}{|l|}{$\mathrm{N} / \mathrm{C}$ ratio } \\
\hline Area $\left(\mu m^{2}\right)$ & $0.40 \pm 0.09$ & $0.33 \pm 0.07$ & $1.74^{*}$ & $1.27^{*}$ \\
\hline Circumference $(\mu \mathrm{m})$ & $0.60 \pm 0.09$ & $0.54 \pm 0.07$ & $1.50^{*}$ & $1.23^{*}$ \\
\hline Major axis $(\mu \mathrm{m})$ & $0.63 \pm 0.08$ & $0.59 \pm 0.07$ & $1.31^{*}$ & $1.16^{*}$ \\
\hline Minor axis $(\mu \mathrm{m})$ & $0.64 \pm 0.08$ & $0.59 \pm 0.07$ & $1.39^{*}$ & $1.20^{*}$ \\
\hline
\end{tabular}

CMVinf-CP, cytomegalovirus infected cells in smear processed by conventional preparation; CMVinf-LBP, cytomegalovirus infected cells in cytology processed by liquid-based preparation; Histiocyte-CP, histiocytes in smear processed by conventional preparation; Histiocyte-LBP, histiocytes in cytology processed by liquid-based preparation; N, nucleus; C, cytoplasm. ${ }^{*} \mathrm{p}<.05$.

CMV-infected cells was $100.89 \pm 47.87 \mu \mathrm{m}^{2}(\mathrm{t}=6.751, \mathrm{p}<$ .001). The nucleus to cytoplasm ratio of the mean area in CMVinfected cells was $0.33 \pm 0.07(\mathrm{t}=2.781, \mathrm{p}=.008)$ (Tables 2,3$)$.

\section{CMV-infected cell morphology in CP and LBP}

The mean area, circumference, major axis, and minor axis of the cytoplasm, nucleus, and intranuclear inclusion of CMV-infected cells in LBP were larger than those in $\mathrm{CP}(\mathrm{p}<.05)$ (Table 4). However, the mean area, circumference, and major axis of the nucleus to cytoplasm ratio in $\mathrm{CP}$ were larger than those in LBP $(\mathrm{p}<.05)$ (Table 4).

\section{Histiocytes in CP and LBP}

The mean cytoplasmic area of histiocytes in CP was $129.48 \pm$ $47.82 \mu \mathrm{m}^{2}$, which was 1.26 times larger than that in LBP $(\mathrm{t}=$ 2.382, $\mathrm{p}=.019$ ). The mean nuclear area of histiocytes in $\mathrm{CP}$ was $28.35 \pm 9.64 \mu^{2}(t=2.081, p=.039)$. The nucleus to cytoplasm ratio of the mean area, circumference, major axis, and minor axis of histiocytes in $\mathrm{CP}$ was not significantly different from that in LBP.

\section{DISCUSSION}

CMV-infected cells are distinguishable by an enlarged morphology compared to normal counterpart cells. However, the exact numerical measurements of the cytoplasm or nucleus have not been described. In this study, we clarify the sizes of the cytoplasm, nucleus, and intranuclear inclusion in terms of area, circumference, major axis, and minor axis. In $\mathrm{CP}$, the mean cytoplasmic area of $\mathrm{CMV}$-infected cells was 1.47 times larger than that of histiocytes, and the mean nuclear area was 2.61 times larger. In LBP, the mean cytoplasmic area of CMV-infected cells was 2.92 times larger than that of histiocytes, and the mean nuclear area was 4.25 times larger. We measured the size of histiocytes near CMV-infected cells and of those that were singly scattered and well-preserved. Histiocytes were selected as a control for the following reasons: (1) the selected CMV-infected cells were singly scattered with a round cytoplasmic contour, which mainly appeared to be CMV-infected histiocytes, (2) histiocytes are the most frequently encountered cells in bronchial washing cytology specimens, and (3) the exact difference between CMV-infected cells and histiocytes can be easily determined in daily practice.

The mean nuclear cytoplasmic area ratio of the CMV-infected cells was 1.74 times larger than that of histiocytes in $\mathrm{CP}$ and 1.27 times in LBP. The nuclear cytoplasmic area ratio was 0.83 times smaller in LBP $(0.33 \pm 0.07)$ than in CP $(0.40 \pm 0.09)$. Attention should be paid to the relatively high nuclear cytoplasmic ratio in $\mathrm{CP}$ for a practical differential diagnosis of other pathologic cellular alterations, such as neoplastic conditions and reparative changes.

The results of specimen collections from five patients were analyzed as CMV-infected cells in CP, CMV-infected cells in LBP, histiocytes in CP, and histiocytes in LBP. When the four grouped cells were analyzed separately in each patient, the result was the same as shown above. Several reports on compari- 
Table 4. Comparison of cytomegalovirus infected cells on cellular morphology in conventional preparation and liquid-based preparation

\begin{tabular}{|c|c|c|c|c|}
\hline Parameter & CMVinf-LBP $(n=18)$ & CMVinf-CP $(n=69)$ & CMVinf-LBP/CMVinf-CP & $p$-value \\
\hline \multicolumn{5}{|l|}{ Cytoplasm } \\
\hline Area $\left(\mu m^{2}\right)$ & $299.74 \pm 94.90$ & $189.94 \pm 49.27$ & $1.58^{\star}$ & $.000^{*}$ \\
\hline Circumference $(\mu \mathrm{m})$ & $74.59 \pm 17.56$ & $59.26 \pm 10.81$ & $1.26^{*}$ & $.000^{*}$ \\
\hline Major axis $(\mu \mathrm{m})$ & $19.87 \pm 2.92$ & $15.89 \pm 2.26$ & $1.25^{\star}$ & $.000^{*}$ \\
\hline Minor axis $(\mu \mathrm{m})$ & $19.60 \pm 3.29$ & $15.71 \pm 2.27$ & $1.25^{\star}$ & $.000^{*}$ \\
\hline \multicolumn{5}{|l|}{ Nucleus } \\
\hline Area $\left(\mu m^{2}\right)$ & $100.89 \pm 47.87$ & $73.87 \pm 19.54$ & $1.37^{\star}$ & $.030^{*}$ \\
\hline Circumference $(\mu \mathrm{m})$ & $40.00 \pm 7.99$ & $34.92 \pm 5.50$ & $1.15^{\star}$ & $.002^{*}$ \\
\hline Major axis $(\mu \mathrm{m})$ & $11.72 \pm 2.88$ & $9.94 \pm 1.53$ & $1.18^{\star}$ & $.020^{\star}$ \\
\hline Minor axis $(\mu \mathrm{m})$ & $11.58 \pm 2.08$ & $9.91 \pm 1.42$ & $1.17^{\star}$ & $.000^{*}$ \\
\hline \multicolumn{5}{|l|}{$\mathrm{N} / \mathrm{C}$ ratio } \\
\hline Area $\left(\mu m^{2}\right)$ & $0.33 \pm 0.07$ & $0.40 \pm 0.09$ & $0.83^{\star}$ & $.005^{\star}$ \\
\hline Circumference $(\mu \mathrm{m})$ & $0.54 \pm 0.07$ & $0.60 \pm 0.09$ & $0.90^{*}$ & $.021^{*}$ \\
\hline Major axis $(\mu \mathrm{m})$ & $0.59 \pm 0.07$ & $0.63 \pm 0.08$ & $0.94^{*}$ & $.049^{*}$ \\
\hline Minor axis $(\mu \mathrm{m})$ & $0.59 \pm 0.07$ & $0.64 \pm 0.08$ & 0.92 & .053 \\
\hline \multicolumn{5}{|l|}{ INI } \\
\hline Area $\left(\mu m^{2}\right)$ & $36.94 \pm 14.23$ & $29.48 \pm 8.46$ & $1.25^{\star}$ & $.006^{*}$ \\
\hline Circumference $(\mu \mathrm{m})$ & $26.20 \pm 4.81$ & $22.51 \pm 3.23$ & $1.16^{*}$ & $.006^{\star}$ \\
\hline Major axis $(\mu \mathrm{m})$ & $7.05 \pm 1.41$ & $6.27 \pm 1.17$ & $1.12^{\star}$ & $.017^{\star}$ \\
\hline Minor axis $(\mu \mathrm{m})$ & $7.28 \pm 1.48$ & $6.50 \pm 1.06$ & $1.12^{*}$ & $.013^{*}$ \\
\hline \multicolumn{5}{|l|}{$\mathrm{INI} / \mathrm{N}$ ratio } \\
\hline Area $\left(\mu m^{2}\right)$ & $0.38 \pm 0.09$ & $0.41 \pm 0.09$ & 0.93 & .282 \\
\hline Circumference $(\mu \mathrm{m})$ & $0.66 \pm 0.10$ & $0.65 \pm 0.08$ & 1.02 & .597 \\
\hline Major axis $(\mu \mathrm{m})$ & $0.61 \pm 0.09$ & $0.63 \pm 0.09$ & 0.97 & .345 \\
\hline Minor axis $(\mu \mathrm{m})$ & $0.63 \pm 0.08$ & $0.66 \pm 0.09$ & 0.95 & .199 \\
\hline \multicolumn{5}{|l|}{ INI/C ratio } \\
\hline Area $\left(\mu m^{2}\right)$ & $0.12 \pm 0.02$ & $0.16 \pm 0.04$ & $0.75^{\star}$ & $.000^{*}$ \\
\hline Circumference $(\mu \mathrm{m})$ & $0.36 \pm 0.05$ & $0.39 \pm 0.07$ & 0.92 & .075 \\
\hline Major axis $(\mu \mathrm{m})$ & $0.35 \pm 0.04$ & $0.40 \pm 0.06$ & $0.88^{\star}$ & $.002^{*}$ \\
\hline Minor axis $(\mu \mathrm{m})$ & $0.37 \pm 0.05$ & $0.42 \pm 0.07$ & $0.88^{\star}$ & $.010^{*}$ \\
\hline
\end{tabular}

CMVinf-LBP, cytomegalovirus infected cells in cytology processed by liquid-based preparation; CMVinf-CP, cytomegalovirus infected cells in smear processed by conventional preparation; $\mathrm{N}$, nucleus; $\mathrm{C}$, cytoplasm; INI, intranuclear inclusion. ${ }^{*} p<.05$.

son of CP with LBP have highlighted the smaller sizes of the nucleus and cytoplasm in LBP, ${ }^{37-40}$ clear morphologic detail in LBP ${ }^{36}$ higher diagnostic accuracy, ${ }^{33-35}$ and superior quantity of diagnostic cells ${ }^{34}$ or infectious organisms. ${ }^{32}$ Son et al. ${ }^{31}$ reported that, in urine, the cell and nuclear sizes in LBP are larger than in CP. In this study, CMV-infected cells of LBP were significantly larger in the nucleus (1.58 times), cytoplasm (1.37 times), and intranuclear inclusion (1.25 times) areas compared with CP. Enlargement of cells in CMV infection is characteristic and is more easily detectable in LBP than in CP, which may help to increase the diagnostic accuracy. It is unclear why the LBP specimen showed larger CMV-infected cells. It is possible that several factors influenced this result, such as delayed time for the fixative from the moment the specimen was obtained, CMV-infected cellular characteristics, and degeneration. Additional studies with a larger number of cases are needed to determine causative factors for the larger size of histiocytes in CP.

The LBP method has an advantage in detecting CMV-infected cells in daily practice because of the large cytoplasm and nucleus, which are enhanced by a clean background and a small field, which emphasize the enlarged cells and cellular details. However, in this study, the number of CMV-infected cells in LBP tended to be lower than in $\mathrm{CP}$. The $\mathrm{CP}$ slides contained more CMV-infected cells. However, the CMV-infected cells were scattered throughout the entire smear slide. In addition, CMVinfected cells in CP showed a higher nuclear cytoplasmic ratio than those in LBP, which requires a clearer differentiation from other conditions that result in a high nuclear cytoplasmic ratio.

To the best of our knowledge, this is the first analysis of the cytoplasm, nucleus, and intranuclear inclusion of CMV-infected cells that includes numerical measurements of area, circumference, and major and minor axes. The exact extent of CMV-in- 
fected cell enlargement compared to histiocytes was calibrated, and it might be helpful in diagnosing CMV infection in bronchial washing cytology specimens. The preparation method affects the extent of cellular alteration, specifically the cell size, and further study is needed to elucidate the mechanism. In addition, CMV-infected cells in LBP were significantly larger than those in $\mathrm{CP}$.

\section{Conflicts of Interest}

No potential conflict of interest relevant to this article was reported.

\section{Acknowledgments}

This work was supported by the Gachon University Gil Medical Center (Grant number: 2011-01).

\section{REFERENCES}

1. Ribbert H. Über protozoenartige Zellen in der Niere eines syphilitischen Neugeborenen und in der Parotis von Kindern. Zentralbl Allg Pathol 1904; 15: 945-8.

2. Halwachs-Baumann G. Congenital cytomegalovirus infection: epidemiology, diagnosis, therapy. Wien: Springer Vienna, 2011.

3. Jesionek A, Kiolemenoglou B. Ueber einen Befund von protozoenartigen Gebilden in den Organen eines hereditar-luetischen Foetus. Munch Med Wochenschr 1904; 51: 1905-7.

4. Goodpasture EW, Talbot FB. Concerning the nature of "protozoanlike" cells in certain lesions of infancy. Am J Dis Child 1921; 21: 415-25.

5. Cole R, Kuttner AG. A filterable virus present in the submaxillary glands of guinea pigs. J Exp Med 1926; 44: 855-73.

6. Craig JM, Macauley JC, Weller TH, Wirth P. Isolation of intranuclear inclusion producing agents from infants with illnesses resembling cytomegalic inclusion disease. Proc Soc Exp Biol Med 1957; 94: 4-12.

7. Fetterman GH. A new laboratory aid in the clinical diagnosis of inclusion disease of infancy. Am J Clin Pathol 1952; 22: 424-5.

8. Warner NE, McGrew EA, Nanos S. Cytologic study of the sputum in cytomegalic inclusion disease. Acta Cytol 1964; 8: 311-5.

9. An-Foraker SH, Haesaert S. Cytomegalic virus inclusion body in bronchial brushing material. Acta Cytol 1977; 21: 181-2.

10. Frable WJ, Frable MA, Seney FD Jr. Virus infections of the respiratory tract cytopathologic and clinical analysis. Acta Cytol 1977; 21: 32-6.

11. Martin WJ 2nd, McDougall JC. Cytomegalovirus infection with idiopathic pulmonary fibrosis: diagnosis suggested by bronchoalveolar lavage. Chest 1983; 84: 500-2.
12. Duggan MA, Pomponi C, Robboy SJ. Pulmonary cytology of the acquired immune deficiency syndrome: an analysis of 36 cases. Diagn Cytopathol 1986; 2: 181-6.

13. Buchanan AJ, Gupta RK. Cytomegalovirus infection of the lung: cytomorphologic diagnosis by fine-needle aspiration cytology. Diagn Cytopathol 1986; 2: 341-2.

14. Selvaggi SM, Gerber M. Pulmonary cytology in patients with the acquired immunodeficiency syndrome (AIDS). Diagn Cytopathol 1986; 2: 187-93.

15. Solans EP, Yong S, Husain AN, Eichorst M, Gattuso P. Bronchioloalveolar lavage in the diagnosis of CMV pneumonitis in lung transplant recipients: an immunocytochemical study. Diagn Cytopathol 1997; 16: 350-2.

16. Gideon K, Zaharopoulos P. Cytomegalovirus endocervicitis diagnosed by cervical smear. Diagn Cytopathol 1991; 7: 625-7.

17. Hunt JL, Baloch Z, Judkins A, LiVolsi VA, Montone KT, Gupta PK. Unique cytomegalovirus intracytoplasmic inclusions in ectocervical cells on a cervical/endocervical smear. Diagn Cytopathol 1998; 18: 110-2.

18. Henry-Stanley MJ, Stanley MW, Burton LG, Samuelson J. Cytologic diagnosis of cytomegalovirus in cervical smears. Diagn Cytopathol 1993; 9: 364-5.

19. Sekhon HS, Press RD, Schmidt WA, Hawley M, Rader A. Identification of cytomegalovirus in a liquid-based gynecologic sample using morphology, immunohistochemistry, and DNA real-time PCR detection. Diagn Cytopathol 2004; 30: 411-7.

20. Oei AL, Salet-van de Pol MR, Borst SM, van den Berg AP, Grefte JM. "Owl's eye" cells in a cervical smear of a transplant recipient: don't forget to inform the referring physician. Diagn Cytopathol 2007; 35: 227-9.

21. Venkataraman G, Kouria G, Mehrotra S, Hammadeh R, Wojcik $\mathrm{EM}$, Booth CN. Cytomegalovirus inclusions on a cervical pap test: report of a well-known organism at an uncommon site. Diagn Cytopathol 2007; 35: 618-20.

22. Wax TD, Layfield LJ, Zaleski S, et al. Cytomegalovirus sialadenitis in patients with the acquired immunodeficiency syndrome: a potential diagnostic pitfall with fine-needle aspiration cytology. Diagn Cytopathol 1994; 10: 169-72.

23. Santiago K, Rivera A, Cabaniss D, Dhurhar N, Moroz K. Fine-needle aspiration of cytomegalovirus sialadenitis in a patient with acquired immunodeficiency syndrome: pitfalls of diff-quik staining. Diagn Cytopathol 2000; 22: 101-3.

24. Goodman ZD, Gupta PK, Frost JK, Erozan YS. Cytodiagnosis of viral infections in body cavity fluids. Acta Cytol 1979; 23: 204-8.

25. Delfs-Jegge S, Dalquen P, Hurwitz N. Cytomegalovirus-infected cells in a pleural effusion from an acquired immunodeficiency syn- 
drome patient: a case report. Acta Cytol 1994; 38: 70-2.

26. Armbruster C, Schalleschak J, Vetter N, Pokieser L. Pleural effusions in human immunodeficiency virus-infected patients: correlation with concomitant pulmonary diseases. Acta Cytol 1995; 39: 698-700.

27. Katz RL, Alappattu C, Glass JP, Bruner JM. Cerebrospinal fluid manifestations of the neurologic complications of human immunodeficiency virus infection. Acta Cytol 1989; 33: 233-44.

28. Teot LA, Ducatman BS, Geisinger KR. Cytologic diagnosis of cytomegaloviral esophagitis: a report of three acquired immunodeficiency syndrome-related cases. Acta Cytol 1993; 37: 93-6.

29. Zhang X, el-Sahrigy D, Elhosseiny A, Melamed MR. Simultaneous cytomegalovirus infection and Kaposi's sarcoma of the thyroid diagnosed by fine needle aspiration in an AIDS patient: a case report and first cytologic description of the two entities occurring together. Acta Cytol 2003; 47: 645-8.

30. Shi Q, Nilson E, Singh M, David O, Cabay RJ. Uncommon cervical viral cytopathic changes in a liquid-based cytology preparation. Diagn Cytopathol 2012; 40: 1088-9.

31. Son SM, Koo JH, Choi SY, et al. Evaluation of urine cytology in urothelial carcinoma patients: a comparison of CellprepPlus(R) liquidbased cytology and conventional smear. Korean J Pathol 2012; 46: 68-74.

32. Takei H, Ruiz B, Hicks J. Cervicovaginal flora: comparison of conventional pap smears and a liquid-based thin-layer preparation.
Am J Clin Pathol 2006; 125: 855-9.

33. Konofaos $\mathrm{P}$, Tomos $\mathrm{P}$, Malagari $\mathrm{K}$, et al. The role of ThinPrep cytology in the investigation of lung tumors. Surg Oncol 2006; 15: 173-8.

34. Lee KR, Papillo JL, St John T, Eyerer GJ. Evaluation of the ThinPrep processor for fine needle aspiration specimens. Acta Cytol 1996; 40: 895-9.

35. Astall E, Atkinson C, Morton N, Goddard MJ. The evaluation of liquid-based 'Cyto-SED' cytology of bronchioalveolar lavage specimens in the diagnosis of pulmonary neoplasia against conventional direct smears. Cytopathology 2003; 14: 143-9.

36. Hayama FH, Motta AC, Silva Ade P, Migliari DA. Liquid-based preparations versus conventional cytology: specimen adequacy and diagnostic agreement in oral lesions. Med Oral Patol Oral Cir Bucal 2005; 10: 115-22.

37. Kobayashi Y, Uehara T, Ota H. Liquid-based thin-layer cytology can be routinely used in samples obtained via fiberoptic bronchoscope. Acta Cytol 2011; 55: 69-78.

38. Kim S, Owens CL. Analysis of ThinPrep cytology in establishing the diagnosis of small cell carcinoma of lung. Cancer 2009; 117: 51-6.

39. Lee JD, Oh YH, Lee SO, Kim JY. Comparison of diagnostic cytomorphology of atypical squamous cells in liquid-based preparations and conventional smears. Korean J Pathol 2012; 46: 365-9.

40. Norimatsu Y, Shigematsu Y, Sakamoto S, et al. Nuclear characteristics of the endometrial cytology: liquid-based versus conventional preparation. Diagn Cytopathol 2013; 41: 120-5. 